KONSTAN
JURNAL FISIKA DAN PENDIDIKAN FISIKA
Volume 3, Nomor 2, Desember 2018
$\begin{array}{r}\text { E-ISSN : 2460-9129 dan P-ISSN : 2460-9110 } \\ \text { http://jurnalkonstan.ac.id/index.php/jurnal }\end{array}$

\title{
IDENTIFIKASI TINGKAT KONFLIK KOGNITIF MATERI GELOMBANG MEKANIK MELALUI PEMBELAJARAN DENGAN PENDEKATAN KONFLIK KOGNITIF
}

\author{
Zul Hidayatullah $^{1 *}$, Muh. Makhrus ${ }^{1}$, I Wayan Gunada ${ }^{1}$ \\ ${ }^{1}$ Program Studi Pendidikan Fisika FKIP Universitas Mataram \\ Jalan Majapahit No. 62 Mataram
}

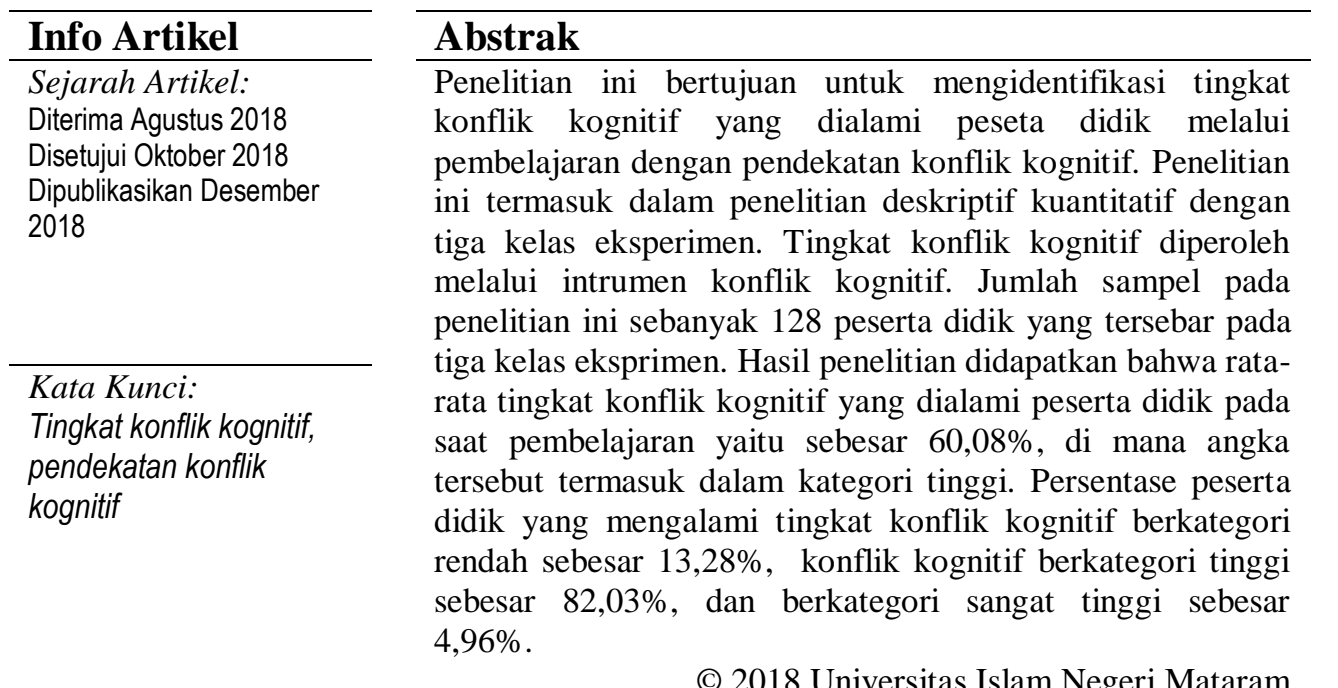

* Corresponding Author: zulhidayatullah5@gmail.com

Alamat korespodensi:

Gedung Pasca Sarjana Lantai 3 Kampus 2 UIN Mataram, Jl. Gajah Mada 100 Jempong Mataram, Indonesia

Email: jurnalkonstan@uinmataram.ac.id 


\section{PENDAHULUAN}

Belajar dan pembelajaran merupakan dua istilah yang selalu berkaitan. Belajar adalah suatu proses yang kompleks yang dapat terjadi pada diri setiap orang sepanjang hidupnya. Pembelajaran merupakan perubahan yang bertahan lama dalam perilaku, atau dalam kapasitas berperilaku dengan cara tertentu, yang dihasilkan dari praktik atau bentuk-bentuk pengalaman lainnya [1]. Guru selaku pelaksana pendidikan memegang peranan yang sangat penting dalam proses pembelajaran, khususnya pada pembelajaran fisika.

Fisika merupakan bagian dari Ilmu Pengetahuan Alam (IPA) atau sains. Sains tidak hanya terdiri dari kumpulan yang terisolasi satu dengan lainnya melainkan kumpulan ilmu pengetahuan yang terorganisasi secara sistermatis. Sains dapat dipandang sebagai proses, produk, dan sikap ilmiah. Sains sebagai produk berbentuk konsep, prinsip, teori, dan hukum. Sains sebagai proses dipandang sebagai metode ilmiah dan sebagai sikap yaitu jujur, terbuka, objektif, dan kritis [2]. Fisika merupakan mata pelajaran yang berfungsi untuk memperluas wawasan pengetahuan tentang materi dan energi, meningkatkan keterampilan ilmiah, menumbuhkan sikap ilmiah, dan kesadaran/kepedulian pada produk teknologi melalui penerapan teori maupun prinsip fisika yang sudah dikuasai sebelumnya. Pernyataan tersebut sejalan dengan pendapat Sirait [3] yang mengatakan bahwa fisika merupakan salah satu cabang IPA yang pada dasarnya bertujuan untuk mempelajari dan menganalisis pemahaman kuantitatif gejala dan proses alam dan sifat zat beserta penerapannya.

Hasil observasi dan wawancara yang dilakukan peneliti pada peserta didik dan guru mata pelajaran fisika kelas XI MAN 2 Mataram, diperoleh bahwa mata pelajaran fisika sering dianggap sebagai pelajaran yang sulit, terlalu banyak rumus, dan membosankan. Masalah ini akan membawa pola pikir peserta didik pada pembelajaran yang sangat monoton. Konsep fisika peserta didik juga masih banyak yang mengalami kekeliruan. Konsep yang keliru ini terjadi karena peserta didik tidak dapat menghubungkan antara pengetahuan yang telah ia miliki dengan konsep baru yang dipelajari di sekolah. Penelitian Setyowati et al. [4] menyatakan pembelajaran pada mata pelajaran fisika dirasakan sulit oleh peserta didik, karena sebagian besar peserta didik belum mampu menghubungkan antara materi yang dipelajari dengan pengetahuan yang digunakan. Hasil penelitian tersebut sesuai dengan pendapat Baser [5] yang menyatakan pembelajaran fisika memiliki banyak konsep yang abstrak dan tidak bisa diamati secara langsung, ini menyebabkan peserta didik memiliki banyak konsep alternatif.

Terkait dengan permasalahan tersebut, maka perlu dilakukan perbaikan dalam kegiatan pembelajaran agar peserta didik memiliki konsep yang utuh dan pemahaman konsep peserta didik dapat meningkat. Salah satu alternatif pemecahan masalahnya adalah dengan menggunakan pendekatan konflik kognitif. Lee et al. [6], konflik kognitif adalah sebuah keadaan di mana peserta didik merasa adanya ketidakcocokan antara struktur kognitif mereka dengan keadaan lingkungannya. Pendekatan konflik kognitif menghadapkan peserta didik pada situasi yang bertentangan dengan konsep awal yang dimiliki, kemudian diarahkan pada percobaan atau demonstrasi untuk membuktikan kebenaran konsep tersebut. 
Teori konstruktivisme merupakan landasan dari pendekatan konflik kognitif. Pembentukan pengetahuan berdasarkan teori konstruktivis yaitu pengetahuan tidak dapat ditransfer begitu saja dari guru ke peserta didik, tetapi harus diinterpretasikan sendiri oleh masing-masing peserta didik [7]. Esensi dari teori konstruktivisme adalah ide bahwa peserta didik harus menemukan dan mentransformasikan suatu informasi kompleks ke situasi lain dan apabila dikehendaki informasi itu menjadi milik mereka sendiri [8]. Teori konstruktivis Piaget menyatakan pembelajaran terjadi ketika anak-anak mengalami konflik kognitif dan terlibat dalam asimilasi dan akomodasi untuk membangun atau mengubah struktur-struktur internalnya [9]. Teori konstruktivisme Piaget juga mengatakan ketika seseorang membangun ilmu pengetahuannya, maka untuk membentuk keseimbangan ilmu yang lebih tinggi diperlukan asimilasi, yaitu kontak atau konflik kognitif yang efektif antara konsep lama dengan kenyataan baru [10].

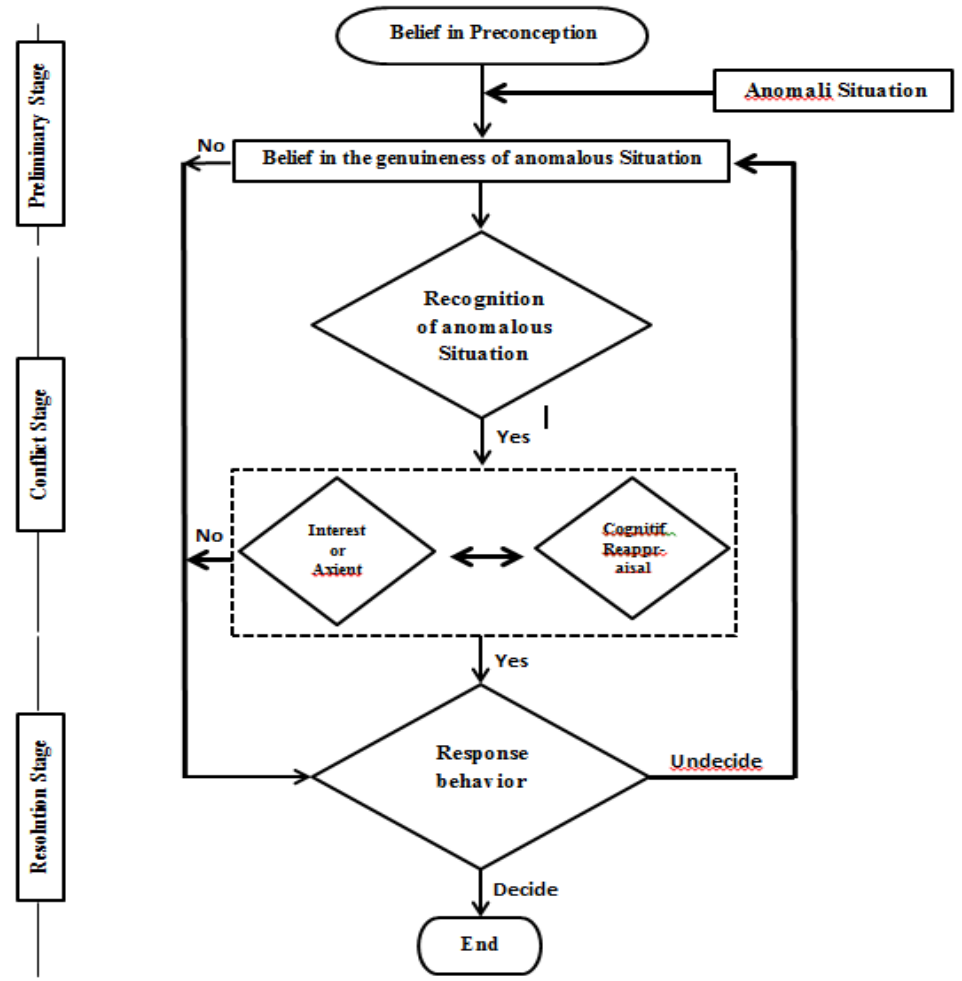

Gambar 1. Proses konflik kognitif Lee et al. (2003:589)

Fase-fase dalam pendekatan konflik kognitif didasarkan pada pendapat Lee et al. [6] yakni fase permulaan (preliminary stage), fase konflik (conflict stage), dan fase penyelesaian (resolution stage) (Gambar 1).

Fase permulaan (preliminary stage) merupakan proses di mana seorang peserta didik memiliki kepercayaan terhadap konsep awal yang sudah dimiliki dan 
guru menciptakan situasi anomali melalui percobaan atau demonstrasi yang bertentangan dengan konsep awal peserta didik. Fase konflik (conflict stage) guru mengamati respon peserta didik terhadap situasi anomali yang diberikan serta diharapkan peserta didik mengalami pertentangan dalam struktur kognitifnya atas konsep yang mereka percaya sebelumnya. Fase penyelesaian (resolution stage) berisi usaha peserta didik dengan bimbingan guru dalam menyelesaikan konflik dalam struktur kognitifnya untuk mendapatkan kesimpulan atau konsep baru yang sesuai dengan konsep ilmiah yang sesungguhnya.

Pendekatan konflik kognitif menurut Lee et al. [6] mengasumsikan empat konstruksi psikologis dalam konflik kognitif, yaitu: 1. Recognition of anomalous (menyadari keadaan menyimpang); 2. Interest (merasa ingin tahu, berminat); 3. Anxiety (kecemasan); 4. Cognitive reappraisal of situation (upaya menentukan solusi konflik dan permasalahannya). Pembelajaran dengan pendekatan konflik kognitif memberikan kesempatan kepada peserta didik untuk mengungkapkan konsepsinya dan mengkritisi pembelajaran yang berbeda dengan konsepsinya.

Penelitian ini bertujuan untuk mengidentifikasi tingkat konflik kognitif pada saat proses pembelajaran dengan pendekatan konflik kognitif.

\section{METODE PENELITIAN}

Jenis penelitian yang digunakan adalah penelitian deskriptif kuantitatif. Perlakuan yang diberikan berupa pendekatan konflik kognitif dan tingkat konflik kognitif diukur melalui instrumen tingkat konflik kognitif. Perlakuan berupa pendekatan konflik kognitif diberikan sebanyak 5 kali pertemuan. Besarnya konflik kognitif yang dialami peserta didik pada saat pembelajaran diukur dengan lembar angket yang diisi peserta setelah pembelajaran. Skor dan kategori tingkat konflik kognitif dapat diamati pada Tabel 1 berikut ini.

Tabel 1. Kategori tingkat konflik kogntif peserta didik

\begin{tabular}{cl}
\hline Skor & \multicolumn{1}{c}{ Kategori } \\
\hline $0-25$ & Rendah \\
\hline $25 \leq \mathrm{X}<50$ & Sedang \\
\hline $50 \leq \mathrm{X}<75$ & Tinggi \\
\hline $75 \leq \mathrm{X}<100$ & Sangat Tinggi \\
\hline
\end{tabular}

Populasi dalam penelitian ini adalah seluruh peserta didik kelas XI MIA di MAN 2 Mataram tahun ajaran 2017/2018 yang berjumlah 6 kelas. Sampel yang digunakan dipilih dengan menggunakan teknik purposive sampling dan terpillih tiga kelas yang dijadikan kelas eksperimen. 


\section{HASIL DAN PEMBAHASAN}

Hasil analisis tingkat konflik kognitif peserta didik dapat dilihat pada Tabel 2 berikut. Berdasarkan tabel tersebut dapat dilihat tingkat konflik kognitif pada peserta didik di tiga kelas eksperimen termasuk dalam kategori tinggi. Tingkat konflik kognitif untuk setiap submateri pada materi gelombang mekanik termasuk kategori tinggi pada setiap kelas eksperimennya dengan rentang skor dari 50 sampai 74.

Tabel 2. Tingkat Konflik Kognitif pada saat Pembelajaran

\begin{tabular}{lccccccc}
\hline \multirow{2}{*}{ Kelas } & \multicolumn{4}{c}{ Tingkat Konflik Kognitif } & Rata-rata & Kategori \\
\cline { 2 - 6 } & $\mathbf{A}$ & $\mathbf{B}$ & $\mathbf{C}$ & $\mathbf{D}$ & $\mathbf{E}$ & & \\
\hline $\begin{array}{l}\text { Eksperimen } \\
1\end{array}$ & 58,13 & 55,98 & 55,02 & 51,19 & 51,43 & 54,35 & Tinggi \\
\hline $\begin{array}{l}\text { Eksperimen } \\
2\end{array}$ & 64,16 & 56,68 & 62,56 & 56,41 & 70,05 & 61,97 & Tinggi \\
\hline $\begin{array}{l}\text { Eksperimen } \\
3\end{array}$ & 73,76 & 59,99 & 58,44 & 61,81 & 61,55 & 63,11 & Tinggi \\
\hline
\end{tabular}

Keterangan: A: Pemantulan Gelombang, B: Pembiasan Gelombang, C: Interferensi, D: Gelombang Tali, E: Gelombang Stationer. berikut.

Hasil analisis tingkat konflik kognitif dapat dilihat pula pada Gambar 2

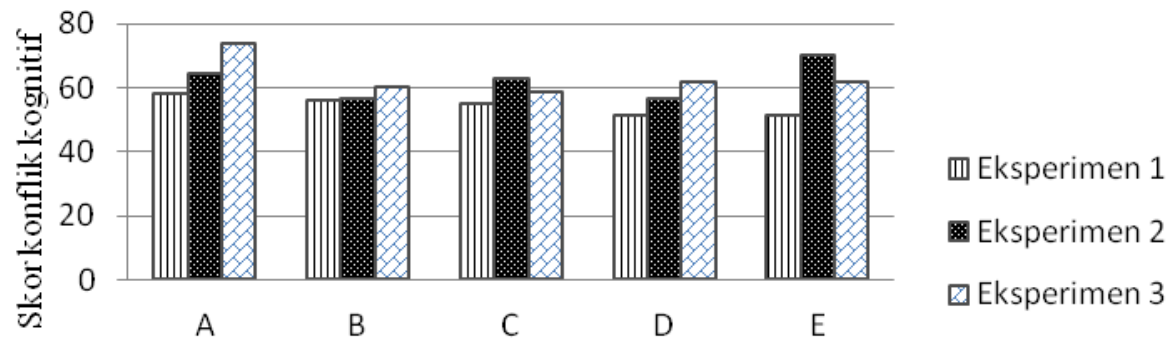

A: Pemantulan Gelombang, B: Pembiasan Gelombang, C: Interferensi, D: Gelombang Tali, E: Gelombang Stationer.

Gambar 2. Perbandingan Tingkat Konflik Kognitif pada Ketiga Kelas Eksperimen

Penelitian ini mengukur tingkat konflik kognitif peserta didik saat pembelajaran dengan pendekatan konflik kognitif. Tingkat konflik kognitif yang diukur mengasumsikan empat konstruksi psikologis dalam konflik kognitif, yaitu: 1. Recognition of anomalous (menyadari keadaan menyimpang); 2. Interest (merasa ingin tahu, berminat); 3.Anxiety (kecemasan); 4. Cognitive reappraisal of situation (upaya menentukan solusi konflik dan permasalahannya). Rata-rata tingkat konflik kognitif yang dialami peserta didik pada saat pembelajaran pada 
tiap kelas eksperimen termasuk dalam kategori tinggi. Konflik kognitif yang tinggi akan menyebabkan peserta didik mengalami perubahan konseptual. Perubahan konseptual ini dapat terjadi setelah peserta didik menyadari adanya ketidakcocokan pengetahuan awalnya dengan konsep ilmiahnya melalui proses pembelajaran dengan pendekatan konflik kognitif.

Berdasarkan hasil analisis tingkat konflik kognitif, diketahui bahwa ketiga kelas eksperimen mengalami tingkat konflik kognitif yang tinggi. Fakta ini disebabkan karena banyaknya peserta didik yang memiliki konsepsi yang salah, sehingga ketika diberikan pembelajaran dengan pendekatan konflik kognitif untuk membuktikan konsep ilmiah yang sebenarnya, banyak peserta didik yang mengalami ketidakcocokan dengan konsepsinya dan akhirnya mengalami tingkat konflik kognitif yang tinggi.

Konflik kognitif yang tinggi terjadi ketika peserta didik menyadari adanya keadaan anomali atau keadaan menyimpang setelah mengamati demonstrasi yang berkaitan dengan materi gelombang mekanik. Demonstrasi ini merupakan salah satu metode untuk menimbulkan konflik kognitif pada peserta didik. Hasil pengamatan peserta didik terhadap demonstrasi ini berbeda-beda, sehingga menimbulkan konsepsi yang beragam. Konsepsi yang beragam ini membuat rasa ingin tahu peserta didik meningkat, karena penasaran akan konsep ilmiahnya dan pada akhirnya rasa ingin tahu peserta didik untuk mencari konsep ilmiah akan membawa peserta didik pada upaya untuk menentukan solusi atas permasalahannya atau bahkan peserta didik akan menjadikannya penghubung antara konsep awalnya dengan konsep yang baru didapatkan. Fakta ini sesuai dengan pendapat Foster [11], yang mengatakan konflik kognitif terjadi ketika keseimbangan mental peserta didik terganggu oleh pengalaman (disebut sebagai "anomali") yang tidak sesuai dengan pemahaman mereka saat ini. Berdasarkan hasil pretest terungkap bahwa prakonsepsi (prior knowledge) peserta didik terhadap suatu konsep fisika cukup bervariasi, yaitu terdapat antara tiga sampai enam macam konsepsi peserta didik. Hal ini menunjukkan bahwa peserta didik masuk ke dalam kelas tidak dengan kepala kosong (blank mind), tetapi mereka telah memiliki berbagai gagasan tentang peristiwa-peristiwa alam yang dibangunnya melalui proses belajar informal dalam rangka memberi makna terhadap pengalaman mereka sehari-hari.

Tingkat konflik kognitif peserta didik pada ketiga kelas eksperimen termasuk dalam kategori tinggi dan rata-rata tingkat konflik kognitif peserta didik berkisar dari $50 \%$ sampai $63 \%$. Konflik kognitif tertinggi terjadi pada submateri pemantulan gelombang dengan persentase sebesar $65,35 \%$, karena pada materi tersebut peserta didik banyak memiliki konsepsi yang salah, sehingga setelah diberikan demonstrasi yang menimbulkan konflik kognitif serta diberikan penjelasan tentang konsep ilmiahnya, peserta didik mengalami perubahan konseptual. Perubahan konseptual yang terjadi pada peserta didik yaitu 1) pada pertemuan pertama tentang materi hukum pemantulan gelombang, peserta didik banyak menjawab bahwa sudut pantul sama dengan 2 kali sudut datang dan mengatakan bahwa hukum pemantulan hanya berlaku pada cahaya. Demontrasi yang diamati oleh peserta didik membuat peserta didik mulai ragu akan konsep awal yang dimilikinya dan mulai mencari kebenaran atas permasalahan tersebut, sehingga terjadilah perubahan konseptual ke konsep ilmiah; 2) pada pertemuan 
kedua tentang pembiasan gelombang, banyak peserta didik yang keliru antara gelombang dibiaskan mendekati garis normal atau menjauhi garis normal ketika gelombang datang melalui medium rapat menuju medium kurang rapat dan sebaliknya, serta peserta didik masih belum bias membedakan antara pembiasan dan difraksi. Kedua sifat gelombang ini hamper serupa tapi maknanya tak sama. Demonstrasi untuk memunculkan konflik kognitif peserta didik kembali membuat peserta didik mengalami keraguan akan konsepsinya, sehingga terjadilah pembentukan konsep baru yang utuh dan sesuai dengan konsep ilmiahnya; 3) pertemua ketiga tentang interferensi gelombang, peserta didik mengalami tingkat konflik kognitif yang tinggi, karena beranggapan bahwa ketika gelombang berinterferensi, yang terjadi adalah gambar gelombang semakin panjang dan peserta didik beranggapan bahwa selalu terjadi interferensi konstruktif padahal jika gelombang berbeda fase akan terjadi interferensi destruktif (saling meniadakan). Pembelajaran dengan pendekatan konflik kognitif ini mampu membuat peserta didik memperbaiki kesalahan konsepnya; 4) pada pertemuan keempat dan kelimu, peserta didik tidak memahami bentuk gelombang tali dan keliru dalam memahami gelombang stationer ujung bebas dan ujung terikat.

Peserta didik pada ketiga kelas eksperimen memberikan penilaian yang tinggi terhadap konflik kognitif yang terjadi pada dirinya setelah diberikan angket tingkat konflik kognitif. Fakta ini sesuai dengan pendapat Lee et al., [6] yang mengatakan bahwa pembelajaran dengan konflik kognitif memberikan guru kesempatan untuk mengetahui tingkat konflik kognitif peserta didiknya dan memungkinkan terjadinya perubahan konseptual pada peserta didik. Pembelajaran ini membuat peserta didik lebih memahami konsep ilmiahnya.

\section{SIMPULAN DAN SARAN}

Berdasarkan hasil dan pembahasan yang telah dipaparkan dapat disimpulkan bahwa: 1) Tingkat konflik kognitif peserta didik termasuk kategori tinggi saat proses pembelajaran dengan pendekatan konflik kognitif pada materi gelombang mekanik dan rata-rata tingkat konflik kognitif peserta didik berkisar dari $50 \%$ sampai $63 \%$; 2) Konflik kognitif yang tinggi akan menyebabkan peserta didik mengalami perubahan konseptual. Perubahan konseptual ini dapat terjadi setelah peserta didik menyadari adanya ketidakcocokan pengetahuan awalnya dengan konsep ilmiahnya melalui proses pembelajaran dengan pendekatan konflik kognitif, karena pembelajaran dengan pendekatan konflik kognitif ini membawa peserta didik untuk mencari solusi atas permasalahan yang dialami.

\section{DAFTAR PUSTAKA}

[1] Schunk, D.H. 2012. Learning Theories An Educational Perspective. Yogyakarta: Pustaka Pelajar.

[2] Makhrus M., dan Hadiprayitno G. 2012. Penerapan Perangkat Pembelajaran Fisika Berorientasi Pembelajaran IPA Terpadu Tipe Connected. Jurnal Pendidikan dan Pembelajaran 19(2), 237-242. 
[3] Sirait, J. 2012. Pendekatan Pembelajaran Konflik Kognitif Untuk Meningkatkan Penguasaan Konsep Siswa SMA pada Topik Suhu dan Kalor. Jurnal Pendidikan Matematika dan IPA, 1(2).

[4] Setyowati, A., Subali, B., dan Mosik. 2011. Implementasi pendekatan konflik kognitif dalam pembelajaran fisika untuk menumbuhkan kemampuan berpikir kritis siswa SMP kelas VIII. Jurnal Pendidikan Fisika Indonesia, 7(2), 89-96.

[5] Baser, M. 2006. Fostering conceptual change by cognitive conflict based instruction on students' understanding of heat and temperature concepts. Eurasia Journal of Mathematics, Science and Technology Education, 2(2), 96114.

[6] Lee, G., Kwon, J., Park, S. S., Kim, J. W., Kwon, H. G., dan Park, H. K. 2003. Development of an instrument for measuring cognitive conflict in secondary level science classes. Journal of research in science teaching 40(6), 585-603.

[7] Hakiim, L. 2008. Perencanaan Pembelajaran. Bandung: CV Wacana Prima.

[8] Sagala, S. 2009. Konsep dan Makna Pembelajaran untuk Membantu Memecahkan Problematika Belajar dan Mengajar. Bandung: Alfabeta.

[9] Madu, B. C., dan Orji, E. 2011. Effect of Cognitive Conflict Instructional Strategy on Students' Conceptual Change inn Temperature and Heat. SAGE Open: 1-9. 